\title{
Electrochemical Impedance Studies of SOFC Cathodes
}

Hjelm, Johan; Søgaard, Martin; Wandel, Marie; Mogensen, Mogens Bjerg; Menon, Mohan; Hagen, Anke

Published in:

E C S Transactions

Link to article, DOI:

$10.1149 / 1.2729227$

Publication date:

2007

Document Version

Publisher's PDF, also known as Version of record

Link back to DTU Orbit

Citation (APA):

Hjelm, J., Søgaard, M., Wandel, M., Mogensen, M. B., Menon, M., \& Hagen, A. (2007). Electrochemical

Impedance Studies of SOFC Cathodes. E C S Transactions, 7(1), 1261-1270. https://doi.org/10.1149/1.2729227

\section{General rights}

Copyright and moral rights for the publications made accessible in the public portal are retained by the authors and/or other copyright owners and it is a condition of accessing publications that users recognise and abide by the legal requirements associated with these rights.

- Users may download and print one copy of any publication from the public portal for the purpose of private study or research

- You may not further distribute the material or use it for any profit-making activity or commercial gain

- You may freely distribute the URL identifying the publication in the public portal

If you believe that this document breaches copyright please contact us providing details, and we will remove access to the work immediately and investigate your claim 


\title{
Electrochemical Impedance Studies of SOFC Cathodes
}

\author{
J. Hjelm*, M. Søgaard, M. Wandel, M. Menon, M. Mogensen, and A. Hagen \\ Fuel Cells and Solid State Chemistry Department \\ Risoe National Laboratory, DK-4000, Roskilde, Denmark
}

\begin{abstract}
Mixed ion- and electron-conducting composite electrodes consisting of doped ceria and perovskite have been studied by electrochemical impedance spectroscopy (EIS) at different temperatures and oxygen partial pressures. This paper aims to describe the different contributions to the polarisation impedance of the cathode at intermediate operating temperatures. The perovskite is of the La-Sr-Co-Fe type. The EIS response of symmetrical cells with a thick $(\sim 200 \mu \mathrm{m})$ gadolinia doped ceria electrolyte was compared with the impedance contribution of the cathode of a full anode supported cell. The full cells had a Ni-YSZ anode and anode support, a thin YSZ electrolyte, and a CGO barrier layer. The symmetric and full cell cathode responses were compared at open-circuit voltage. Humidified hydrogen was used as the fuel in the full cell measurements. Differential analysis of the impedance data was used to identify frequency ranges where changes occur upon degradation and oxygen partial pressure variations.
\end{abstract}

\section{Introduction}

Reduction of the solid oxide fuel cell, SOFC, operation temperature requires development of cathode materials with improved performance compared to the commonly used LSM cathode, as a large part of the full cell losses at lower operating temperatures $\left(850-600^{\circ} \mathrm{C}\right)$ generally originates from the cathode $(1,9)$. A frequently studied SOFC cathode material for use in intermediate temperature operation is (La, $\mathrm{Sr})(\mathrm{Co}, \mathrm{Fe}) \mathrm{O}_{3}$, LSCF, perovskite, of which $\mathrm{La}_{0.6} \mathrm{Sr}_{0.4} \mathrm{Co}_{0.2} \mathrm{Fe}_{0.8} \mathrm{O}_{3}$ is one of the most commonly used chemical compositions providing a compromise between conductivity, catalytic activity, thermal expansion, and reactivity with the electrolyte $(2,3,4)$. Recently, cathodes of the composition $\mathrm{La}_{0.58} \mathrm{Sr}_{0.4} \mathrm{Co}_{0.2} \mathrm{Fe}_{0.8} \mathrm{O}_{3-\delta}$ were shown to exhibit greater performance than state-of-the art composite LSM-YSZ cathodes (8). The stability of this type of electrode was fair, with an average degradation rate of $1.5 \%$ per $1000 \mathrm{~h}$. In this contribution composite cathodes consisting of $\mathrm{La}_{0.58} \mathrm{Sr}_{0.4} \mathrm{Co}_{0.2} \mathrm{Fe}_{0.8} \mathrm{O}_{3-\delta}$ and gadolinia doped ceria, CGO, were studied on CGO tape and as the cathode on a full cell. A thin dense barrier layer consisting of CGO, deposited by pulsed laser deposition, PLD, was used as a diffusion barrier to avoid chemical reaction between the LSCF and the YSZ electrolyte. It is well known that the impedance response of whole (full) fuel cells is complicated and many processes with different time constants contribute to the overall response. In order to study the response from a single electrode of the full cell (e.g. the cathode) one may carry out electrochemical impedance spectroscopy, EIS, measurements while changing the conditions on only one side of the cell at a time (single-sided gas changes) and study how the changes on each side affect the impedance response. It is of 
great interest to identify processes that are performance limiting or responsible for the degradation of these composite LSCF cathodes. The recently described technique of differential analysis of impedance data has been shown to enhance and aid in graphically representing changes between pairs of impedance spectra $(15,16)$. Further, this technique helps to identify frequency ranges (i.e. possible ranges of time constants) of electrode contributions without any assumptions regarding equivalent circuit or physical model having to be made, but instead may aid in selection of an appropriate circuit model. In the first part of this contribution differential analysis of impedance data is applied to datasets recorded using symmetrical cells consisting of (LSCF+GCO10/CGO10/LSCF+CGO10). Frequency intervals where changes occur upon oxygen partial pressure variations and degradation are identified. In the second part of this contribution the above approach is used to compare the cathode response and degradation from a full cell (NiYSZ/YSZ/CGO/LSCF+CGO) with the response of the symmetrical cells under similar conditions. Further, the activation energies of the cathodes and of the full cells are reported.

\section{Experimental}

\section{$\underline{\text { Symmetric Cells }}$}

The cathode investigated in this study is a composite consisting of $50 / 50 \mathrm{wt} \%$ $\mathrm{La}_{0.58} \mathrm{Sr}_{0.4} \mathrm{Fe}_{0.8} \mathrm{Co}_{0.2} \mathrm{O}_{3-\delta}$ (LSCF) and $\mathrm{Ce}_{0.9} \mathrm{Gd}_{0.1} \mathrm{O}_{1.95}$ (CGO10). The CGO10 was calcined at $1100^{\circ} \mathrm{C}$ for $2 \mathrm{~h}$ and the $\mathrm{LSCF}$ has been calcined at $900^{\circ} \mathrm{C}$ for $2 \mathrm{~h}$ prior to the fabrication of the screen printing ink. The SOFC cathode was applied to both sides of a 5 $\times 5 \mathrm{~cm}^{2}$ CGO10 electrolyte using screen printing technology. This symmetric cell was sintered at $1080^{\circ} \mathrm{C}$ for $2 \mathrm{~h}$. This large symmetric cell was cut into smaller pieces with a size of $0.40(1) \times 0.40(1) \mathrm{cm}^{2}$. The cathode preparation follows closely that published by Uhlenbruck et al (7) and Tietz et al (8) except that we use a composite cathode.

Platinum paste was painted on both sides of four $0.4 \times 0.4 \mathrm{~cm}^{2}$ symmetric cells in order to obtain good electrical contact between the cathode and the contacting platinum mesh. The samples were heated to $980^{\circ} \mathrm{C}$ in order to sinter the platinum paste. The test rig used for the experiments had four sample positions. In this way we also obtain information on the reproducibility, reliability and uncertainty on the electrochemical performance of the cells. The samples were heated in atmospheric air in the following sequence $741^{\circ} \mathrm{C} \rightarrow 750^{\circ} \mathrm{C} \rightarrow 700^{\circ} \mathrm{C} \rightarrow 650^{\circ} \mathrm{C} \rightarrow 600^{\circ} \mathrm{C} \rightarrow 550^{\circ} \mathrm{C} \rightarrow 600^{\circ} \mathrm{C} \rightarrow 650^{\circ} \mathrm{C}$ $\rightarrow 700^{\circ} \mathrm{C} \rightarrow 750^{\circ} \mathrm{C} \rightarrow 800^{\circ} \mathrm{C} \rightarrow 850^{\circ} \mathrm{C} \rightarrow 800^{\circ} \mathrm{C} \rightarrow 750^{\circ} \mathrm{C}$. At each temperature an impedance spectrum was recorded for each of the sample positions. The electrochemical measurement was carried out using a Hioki impedance analyzer in the frequency range $100 \mathrm{kHz}-0.1 \mathrm{~Hz}$ at open circuit voltage (OCV). After the temperature investigation the sample was held at $750^{\circ} \mathrm{C}$ and impedance spectra were recorded with a regular interval of approximately $4 \mathrm{~h}$.

For the oxygen partial pressure variation three symmetric samples with platinum paste were randomly selected and placed in our test rig. In the fourth position a type-S thermocouple was placed in order to ensure a correct temperature measurement. The electrochemical measurements were carried out using a Solartron 1260 in the frequency range $1 \mathrm{MHz}-0.0134 \mathrm{~Hz}$. A flow of $90 \mathrm{sccm}$ was passed over the samples at all times. The oxygen partial pressure was varied by changing the flow rates of oxygen and nitrogen. The oxygen partial pressure was measured using a zirconia sensor device. The 
samples were heated to $(751 \pm 1)^{\circ} \mathrm{C}$ and impedance spectra were recorded for the three samples at each oxygen partial pressure. After the oxygen partial pressure variation the samples were left in synthetic air $\left(20 \% \mathrm{O}_{2}\right.$ and $\left.80 \% \mathrm{~N}_{2}\right)$ and impedance spectra were recorded for one sample with a time interval of approximately $2 \mathrm{~h}$.

\section{Full Anode Supported Cell}

The same cathode was applied to an anode supported cell. The anode supported cell was of the standard type from the Risoe/Topsoe pre-pilot plant with respect to the anode and the electrolyte. This cell has an anode of a Ni/YSZ cermet and an YSZ electrolyte (5). On top of the YSZ electrolyte a 2-3 $\mu \mathrm{m}$ thick CGO10 layer has been applied using pulsed laser deposition. The CGO layer serves as a protection layer in order to avoid reaction between the YSZ-electrolyte and the LSCF based cathode.

Electrochemical impedance spectroscopy, EIS, measurements were carried out on the full cell using a Solartron 1260 Gain-Phase Analyzer and in-house constructed cell voltage compensation electronics. The cell was sandwiched between ceramic gas distributor plates contacted by metal plates to give the following assembly: Ni-plate/NiYSZ cermet gas distributor plate/Fuel Cell/LSM gas distributor plate/Au-plate. This assembly was mounted in an alumina test house that was placed in a furnace. The test setup and alumina test house has been described in detail in Hendriksen et al (6). The measurements described in this work were carried out at OCV using a sinusoidal current perturbation with a peak amplitude of $80 \mathrm{~mA}$. The fuel cell is referred to as a full cell to distinguish it from the symmetrical cells. All measurements were carried out with a total fuel flow of $24 \mathrm{~L} \mathrm{~h}^{-1}\left(25 \mathrm{ml} \mathrm{min}{ }^{-1} \mathrm{~cm}^{-2}\right)$ and an oxidant flow of $140 \mathrm{~L} \mathrm{~h}^{-1}(146 \mathrm{ml} \mathrm{min}$ $\mathrm{cm}^{-2}$ ) if nothing else is stated. The fuel was humidified hydrogen with $5 \%$ or $21 \%$ water, and the oxidant was either air or oxygen, or a mixture of nitrogen and oxygen. Testing was carried out with the following temperature sequence: $750^{\circ} \mathrm{C} \rightarrow 850^{\circ} \mathrm{C} \rightarrow 800^{\circ} \mathrm{C} \rightarrow$ $750^{\circ} \mathrm{C} \rightarrow 700^{\circ} \mathrm{C} \rightarrow 650^{\circ} \mathrm{C} \rightarrow 600^{\circ} \mathrm{C} \rightarrow 750^{\circ} \mathrm{C}$.

The differential analysis of impedance data was carried out by calculation of the quantity $\Delta \mathrm{S}^{\prime}$ given in equation 1 below and plotting $\Delta \mathrm{S}^{\prime}$ vs $\log f$ :

$$
\Delta S^{\prime}=\left(\frac{\partial Z_{\text {spectrum } 2}^{\prime}}{\partial \log f_{\text {spectrum } 2}}-\frac{\partial Z_{\text {spectrum } 1}^{\prime}}{\partial \log f_{\text {spectrum } 1}}\right)
$$

For a more detailed description of the rationale behind this procedure see references (15) and (16).

\section{Results and Discussion}

\section{$\underline{\text { Oxygen Partial Pressure Variations - Symmetrical Cells }}$}

Figure 1 a) shows impedance spectra measured for one of the samples measured at different oxygen partial pressures. $R_{\mathrm{s}}$ increased by $4 \%$ during the experiment, however, it seemed independent of the $p \mathrm{O}_{2}$. We attribute this increase to a decreased number of contact points between the electrolyte and cathode or a decreased ionic conductivity in the electrolyte. The curves depicted in Figure 1 a) have been shifted such that $R_{\mathrm{S}}$ is 
located at the initial measurement. It is clearly seen that the polarization resistance increases with decreasing $p \mathrm{O}_{2}$. This increase is attributed to an increase in the oxygen gas diffusion resistance and an increase in the oxygen surface exchange resistance with decreasing $p \mathrm{O}_{2} . R_{\mathrm{p}}$ can be described using the expression: $R_{\mathrm{p}}=0.016 p \mathrm{O}_{2}^{-0.44}$. The exponent of -0.44 can be compared with -0.28 measured by Esquirol et al for a noncomposite LSCF-cathode(10). Figure 1b) shows the differential analysis of the impedance spectra shown in Figure 1 a).

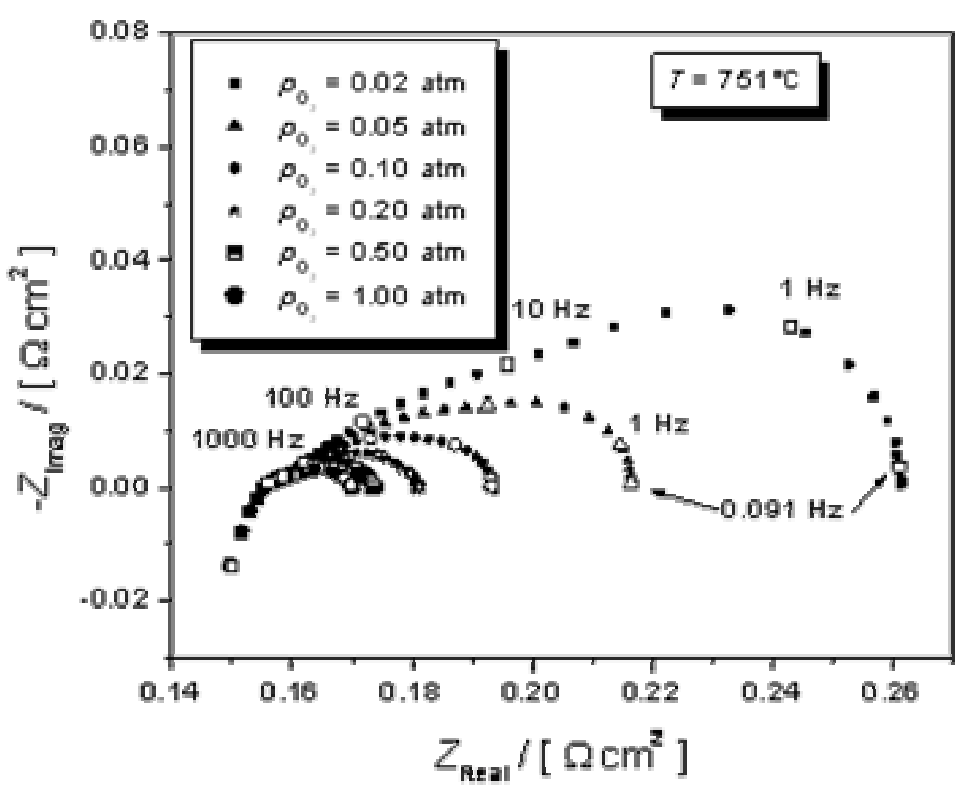

a)

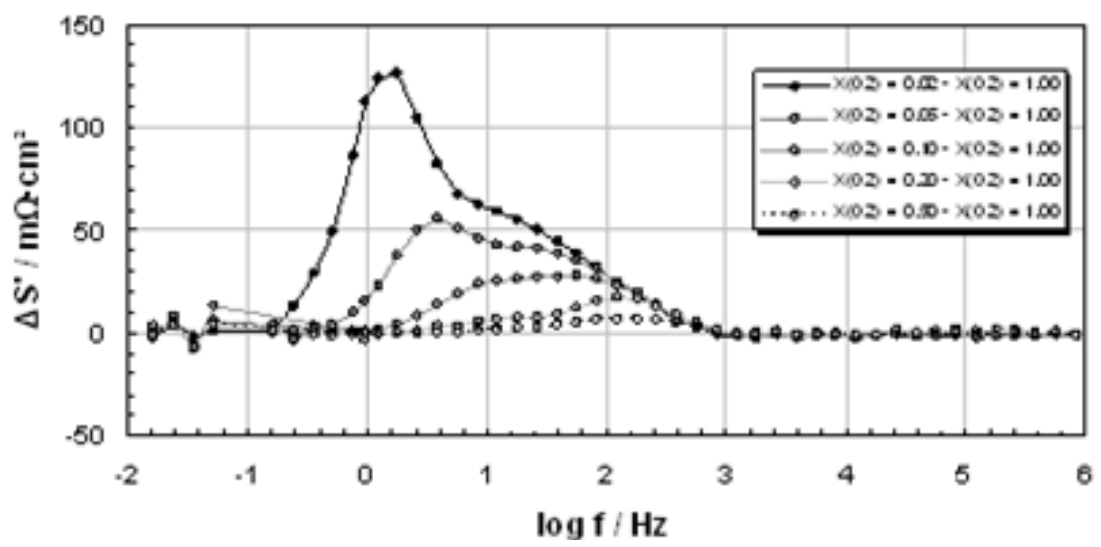

b)

Figure 1. a) Nyquist plot of the impedance response of a symmetric cell $(\mathrm{LSCF}+\mathrm{CGO} 10 / \mathrm{CGO} 10 / \mathrm{LSCF}+\mathrm{CGO} 10)$ at $751^{\circ} \mathrm{C}$ at different oxygen partial pressures, $p \mathrm{O}_{2}$. The frequencies $1 \mathrm{MHz}, 100 \mathrm{kHz}, 10 \mathrm{kHz}, 1 \mathrm{kHz}, 100 \mathrm{~Hz}, 10 \mathrm{~Hz}, 1 \mathrm{~Hz}$ and 0.091 $\mathrm{Hz}$ are marked in the figure as open symbols. Some of the open symbols are also marked with the appropriate frequency. The series resistance, $R_{\mathrm{s}}$, increased by $4 \%$ during the experiment and it was independent of the $p \mathrm{O}_{2}$. All the impedance spectra have been shifted to the first measured value of $R_{\mathrm{s}}$. b) Differential analysis of the impedance data in Figure 1a).

At high oxygen partial pressures the main change in the impedance spectrum occurs in the frequency range $2.5 \mathrm{~Hz}-1000 \mathrm{~Hz}$, as illustrated in Figure $1 \mathrm{~b}$. The change consists of two distinguishable peaks centered at approximately $12 \mathrm{~Hz}$ and $120 \mathrm{~Hz}$, respectively. 
At lower oxygen partial pressures a third peak appears and becomes increasingly important with decreasing oxygen partial pressure. This peak is strongly dependent on $\mathrm{pO}_{2}$ at partial pressures below 0.21 atm. which supports the view that it may be associated, at least in part, to gas-phase diffusion (14).

\section{$\underline{\text { Temperature Variations - Symmetrical Cells }}$}

The polarisation resistance $\mathrm{R}_{\mathrm{p}}$ for the four symmetrical cells measured in the temperature range $550^{\circ} \mathrm{C}-850^{\circ} \mathrm{C}$ is shown in figure 2 along with the activation energy. The activation energy for the symmetric cells as derived from the Arrhenius equation is $101 \mathrm{~kJ} / \mathrm{mol}$. This value is slightly lower than previously reported values that are in the range $115-146 \mathrm{~kJ} / \mathrm{mol}(11,12,13)$.

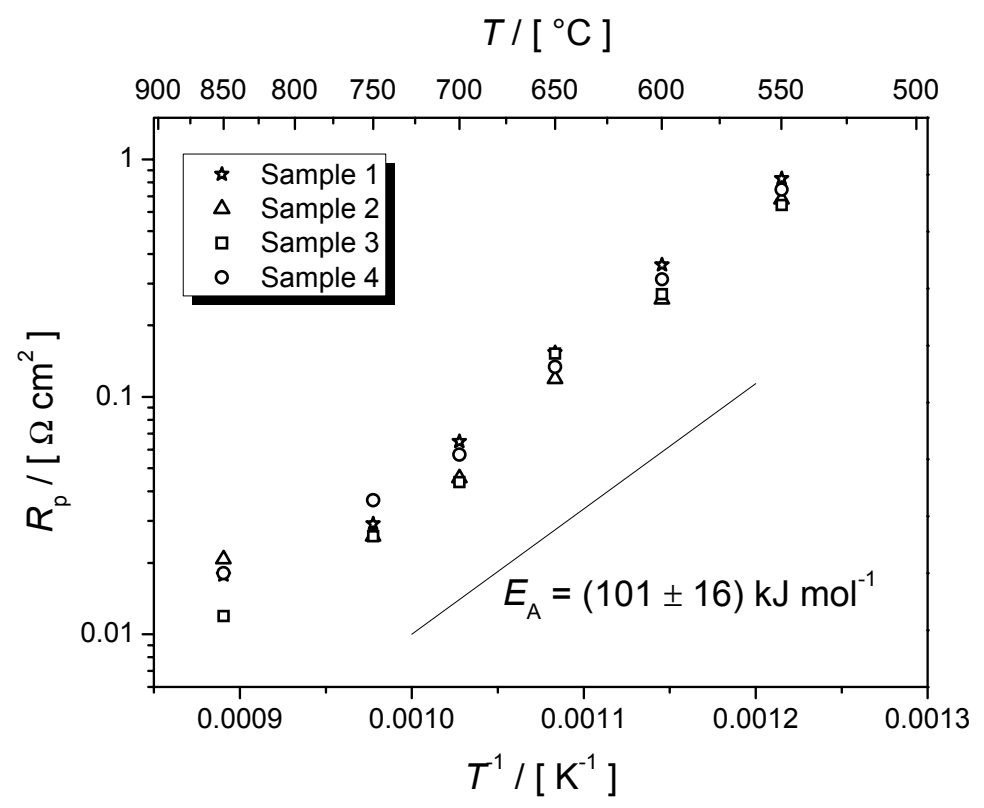

Figure 2. Arrhenius plot of 4 symmetric cells cut from the same sample measured in ambient air in the temperature range $550^{\circ} \mathrm{C}-850^{\circ} \mathrm{C}$. The activation energy $\left(\mathrm{E}_{\mathrm{a}}=101\right.$ $\mathrm{kJ} / \mathrm{mol}$ ) has been derived from the Arrhenius equation.

\section{Degradation - Symmetrical Cells}

Figure 3 shows the polarization resistance, $R_{\mathrm{p}}$, as a function of time, $t$, for two identical symmetric cells. The two tested cells have been cut from the same larger symmetric cell. The first cell has been tested in ambient air and the second cell has been tested in synthetic air (mixture of $20 \% \mathrm{O} 2$ and $80 \% \mathrm{~N}_{2}$ ). The oxygen partial pressure, $p \mathrm{O}_{2}$, for the sample tested in synthetic air was verified using the zirconia sensor device. $R_{\mathrm{p}}$ is seen to increase with time which is referred to as passivation. The numbers given in the figure show the passivation rate. It is clearly seen that the cell in synthetic air passivates by a factor of 2 less than the cell in atmospheric air. We speculate that this may be due to a smaller content of water or carbon dioxide, in the synthetic gas mixture. 


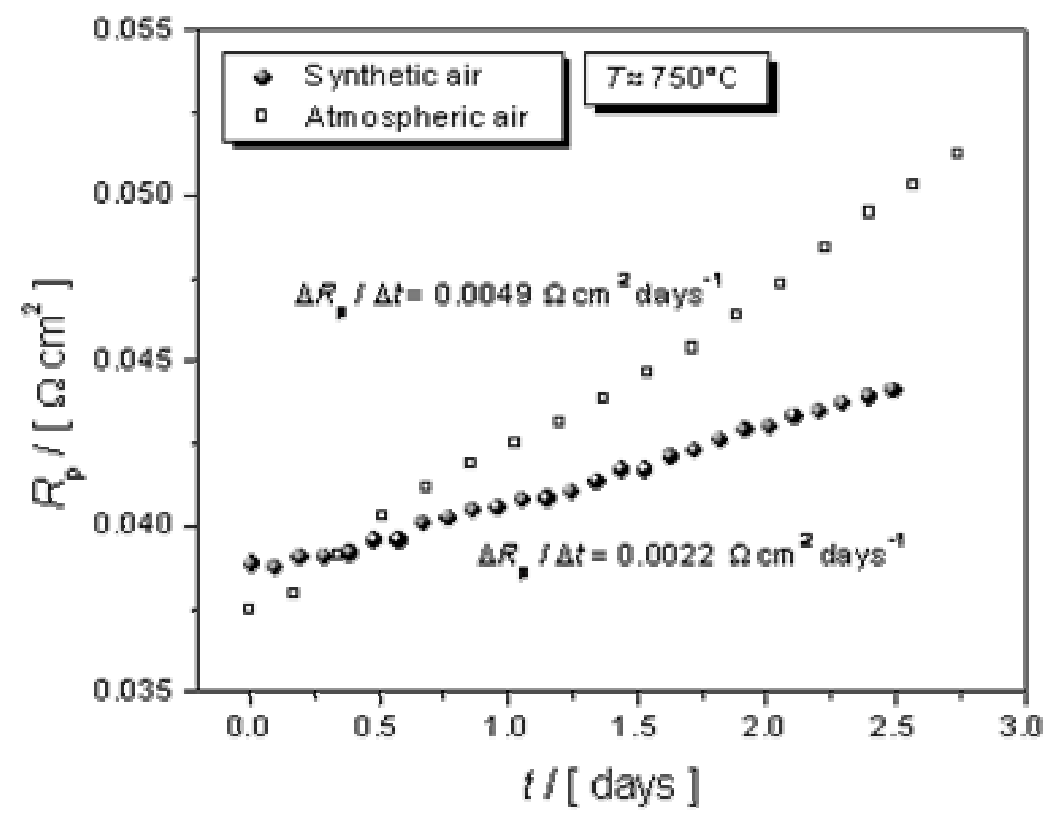

Figure 3. Observed degradation of the polarization resistance of symmetric cells in atmospheric and synthetic air.

Figure 4 illustrates plots of $\Delta S^{\prime}$ vs $\log f$ for impedance spectra recorded before and after degradation for 2.5 days for symmetric cells in atmospheric or synthetic air.

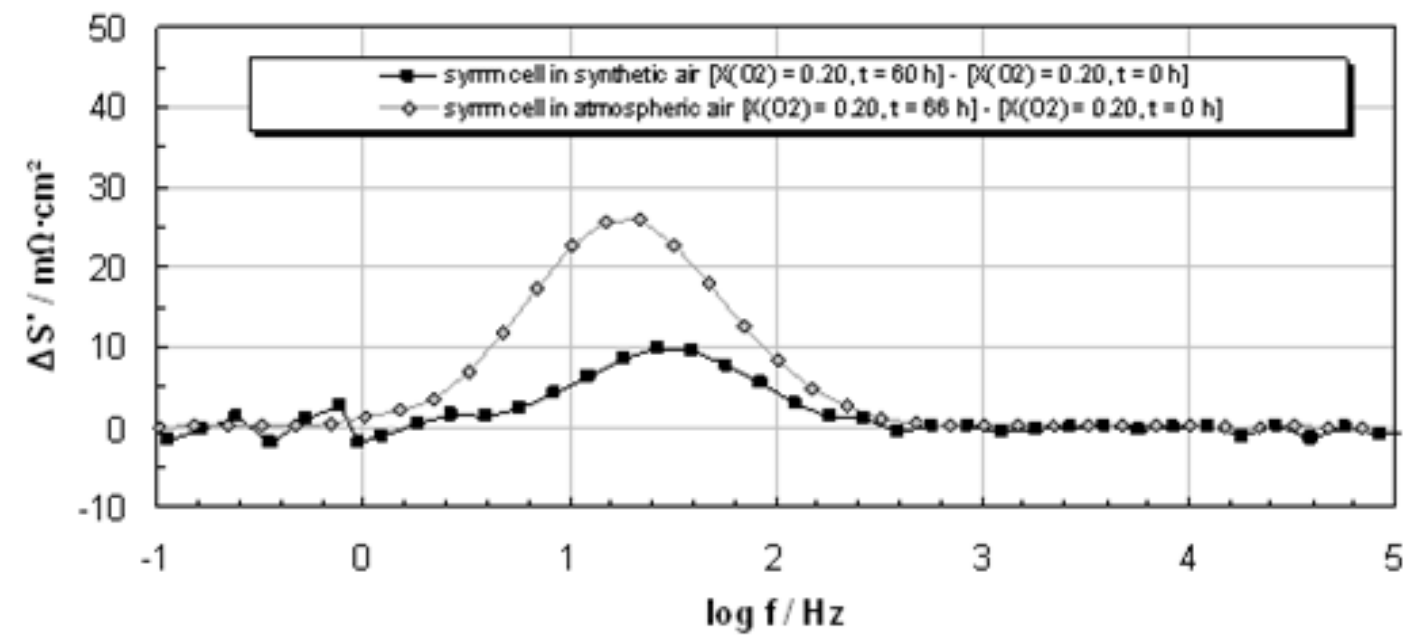

Figure 4. Differential impedance analysis of selected spectra from the data set in Figure 3 highlighting the frequency range affected by the cathode degradation.

Degradation causes a change in the impedance spectrum mainly in the approximate frequency interval $3-150 \mathrm{~Hz}$, which to a great extent coincides with the frequency interval affected by $p \mathrm{O}_{2}$ variations (at $p \mathrm{O}_{2}$ above $0.10 \mathrm{~atm}$ ). This is centered in the frequency interval affected by $p \mathrm{O}_{2}$ changes at high $p \mathrm{O}_{2}$ values $(>0.10 \mathrm{~atm})$ where surface exchange and ion transport may be expected to dominate the impedance spectrum (14). We speculate that this may be due to changes of the electrode surface, that may give rise to changes in the surface exchange and/or surface transport of oxide ions. 
Full Cell Cathode-side Oxygen Partial Pressure Variations - Comparison with $\underline{\text { Symmetrical Cells }}$

Information regarding the frequency ranges dominated by losses on the cathode side of the full cell was obtained by observing the effects on the impedance spectrum as the oxygen partial pressure was varied. The impedance spectra were recorded at a relatively high anode gas water content (21\%) to suppress the anode gas diffusion losses (17). Impedance spectra recorded at low and high oxygen partial pressure are shown in Figure 5 below.

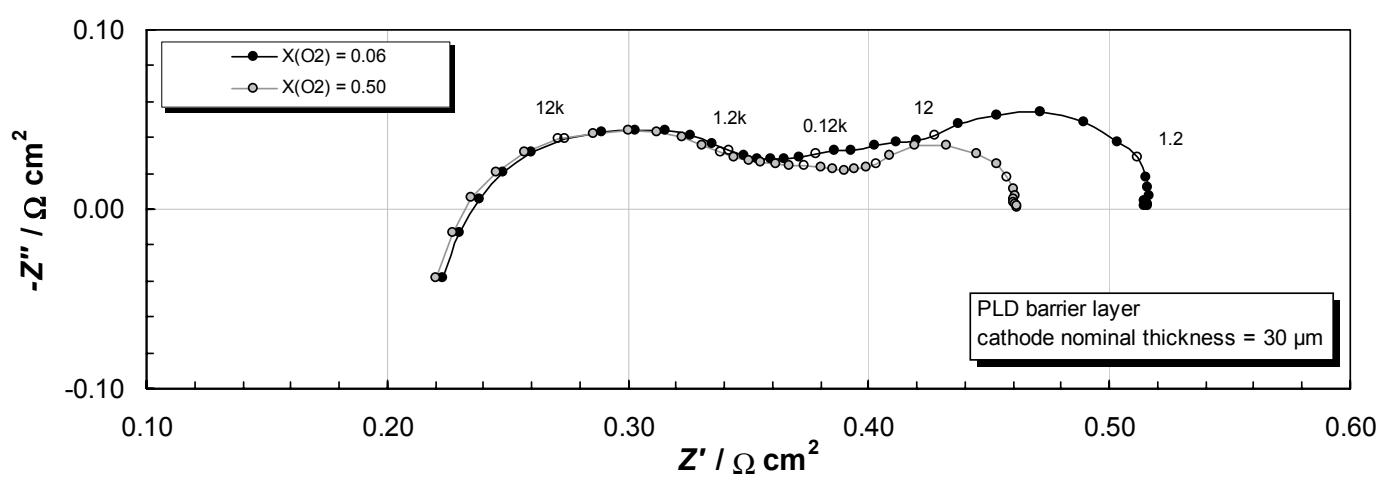

a)

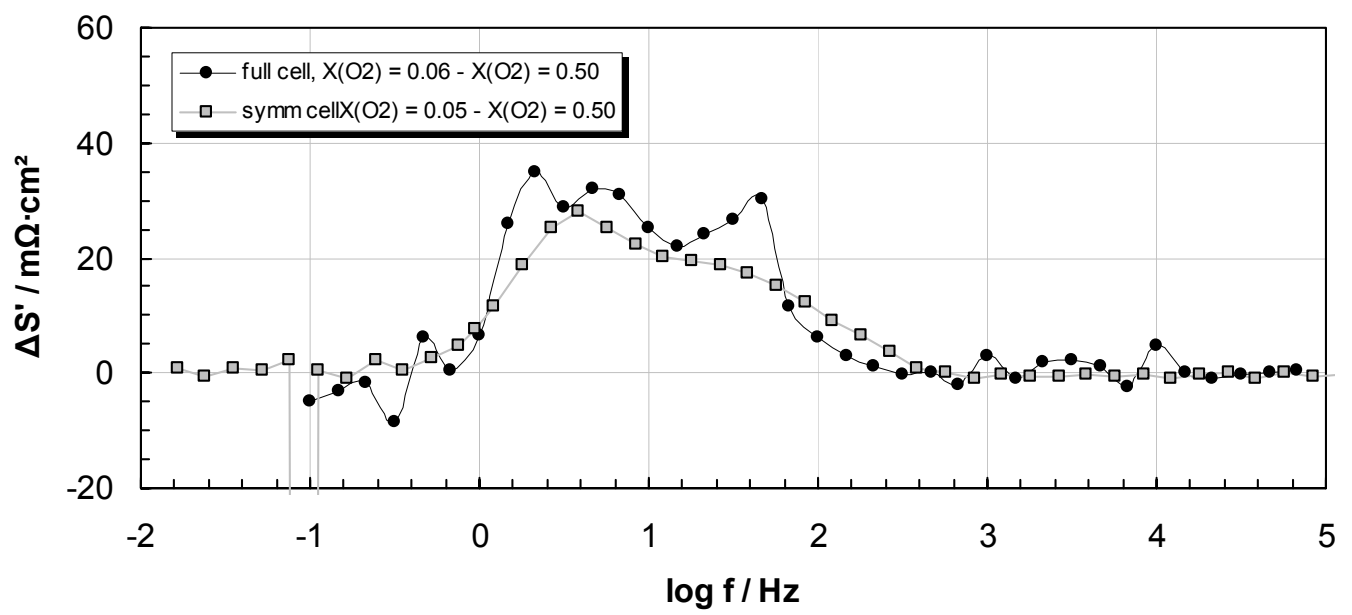

b)

Figure 5. a) Impedance response of an (Ni-YSZ) anode supported fuel cell with an YSZ electrolyte, a CGO barrier layer deposited by pulsed laser deposition, and a screenprinted composite LSCF:CGO cathode (active area $=16 \mathrm{~cm}^{2}$ ) at open-circuit voltage (14test37). Impedance spectra were recorded with humidified hydrogen over the anode $\left(p \mathrm{H}_{2} \mathrm{O}=0.05\right.$ or $\left.0.21 \mathrm{~atm}\right)$ at a total flow rate of $24 \mathrm{l} \mathrm{h}^{-1}\left(25 \mathrm{ml} \mathrm{min} \mathrm{cm}^{-1}\right)$, and with synthetic air (mix of oxygen and nitrogen) over the cathode $\left(p \mathrm{O}_{2}=0.06\right.$ or 0.50$)$ at a flow rate of $1401 \mathrm{~h}^{-1}\left(146 \mathrm{ml} \mathrm{min}^{-1} \mathrm{~cm}^{-2}\right)$. b) Differential data analysis of spectra recorded at constant $\mathrm{pH}_{2} \mathrm{O}$ at the anode and low (0.06 atm.) and high $\mathrm{pO}_{2}(0.50 \mathrm{~atm}$.) at the cathode (data set the same as in Figure 5a). The full cell data is compared to symmetric cell data recorded at the relevant $p \mathrm{O}_{2}$ values.

As can be seen in Figure 5 the two curves representing symmetric cell and full cell data recorded at similar oxygen partial pressures correlate well in the frequency range 
and are within $50 \%$ of each other in magnitude. This observation confirms that the difference observed for the full cell cathode side oxygen partial pressure variation corresponds to the cathode process. Thus, following this difference as a function of treatment of the cell allows the effect on the cathode exclusively to be monitored by recording the full cell response under the appropriate conditions. The same procedure can be applied to follow changes in the anode response exclusively.

\section{$\underline{\text { Full Cell - Temperature Variations }}$}

Impedance spectra of the full cell recorded with air as oxidant are displayed in Figure 6 below. The impedance spectra are characterized by three main arcs. The area-specific polarisation resistance, $R_{\mathrm{p}}$, at open-circuit voltage was determined by subtraction of the series resistance from the low-frequency intersection with the real axis in a Nyquist plot.

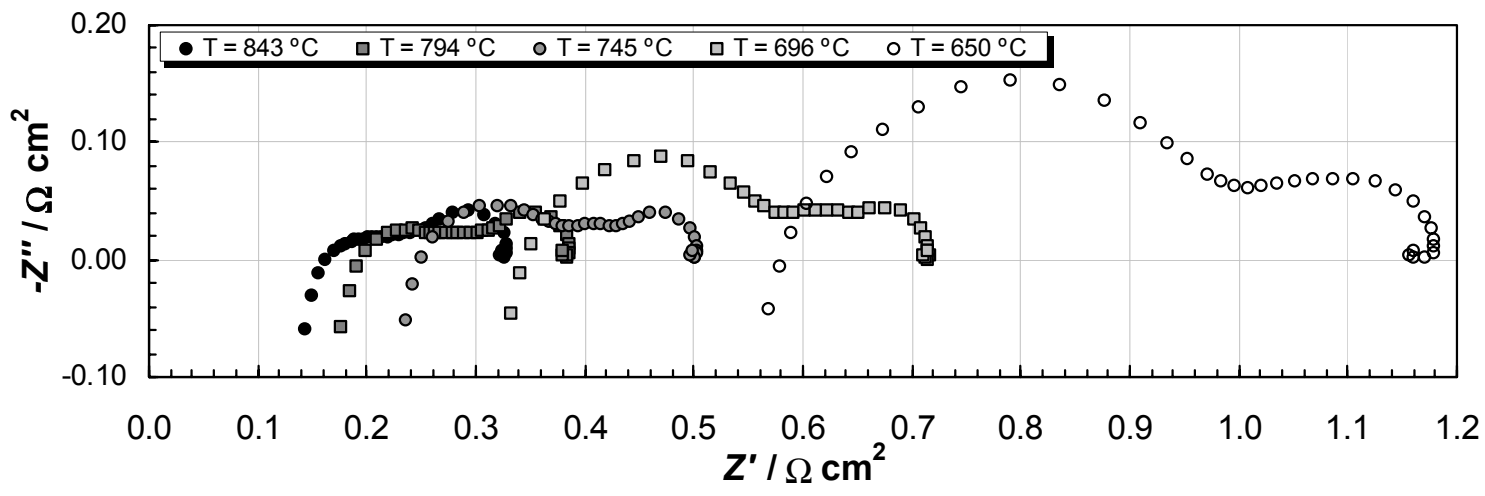

Figure 6. Impedance spectra recorded in the temperature interval $850-650{ }^{\circ} \mathrm{C}$ with air as the oxidant gas. The anode gas was hydrogen with $21 \%$ water.

As illustrated in Figure 6 the high frequency arc is strongly temperature dependent while the (at higher temperatures clearly distinguishable) third arc displays a weak temperature dependence, This indicates that the low frequency arc is associated to a gas diffusion process, while the higher frequency arcs are probably associated with adsorption, surface exchange and ion transport processes. The temperature dependence of full cell polarization resistance is displayed in Figure 7. The apparent full cell activation energy $\left(60 \mathrm{~kJ} \mathrm{~mol}^{-1}\right)$ was derived from the Arrhenius equation. Considering that the activation energy of the electrolyte is $0.9 \mathrm{eV}\left(87 \mathrm{~kJ} \mathrm{~mol}^{-1}\right.$, ref. 18), that gas diffusion processes have very low activation energy and contributes significantly to the overall impedance response, and that the anode activation energy is expected to lie in the range $0.8-1.1 \mathrm{eV}$ (i.e. $77-106 \mathrm{~kJ} \mathrm{~mol}^{-1}$, ref. 18), the observed overall activation energy appears reasonable.

The observed polarization resistance of the full cell at zero bias was $0.26 \Omega \cdot \mathrm{cm}^{2}$ at $745^{\circ} \mathrm{C}$. Previously it was reported that the anode contribution to the polarization resistance for Risoe/Topsoe pilot plant anode supported cells at $750^{\circ} \mathrm{C}$ under similar conditions was $0.18 \Omega \cdot \mathrm{cm}^{2}$ (18). This leaves a contribution from the cathode and the anode diffusion and conversion losses of $0.08 \Omega \cdot \mathrm{cm}^{2}$. This value is in reasonable agreement with the corresponding value of $R_{\mathrm{p}}$ measured in air at $750^{\circ} \mathrm{C}$ using symmetrical cells $\left(0.03 \Omega \cdot \mathrm{cm}^{2}\right)$. 


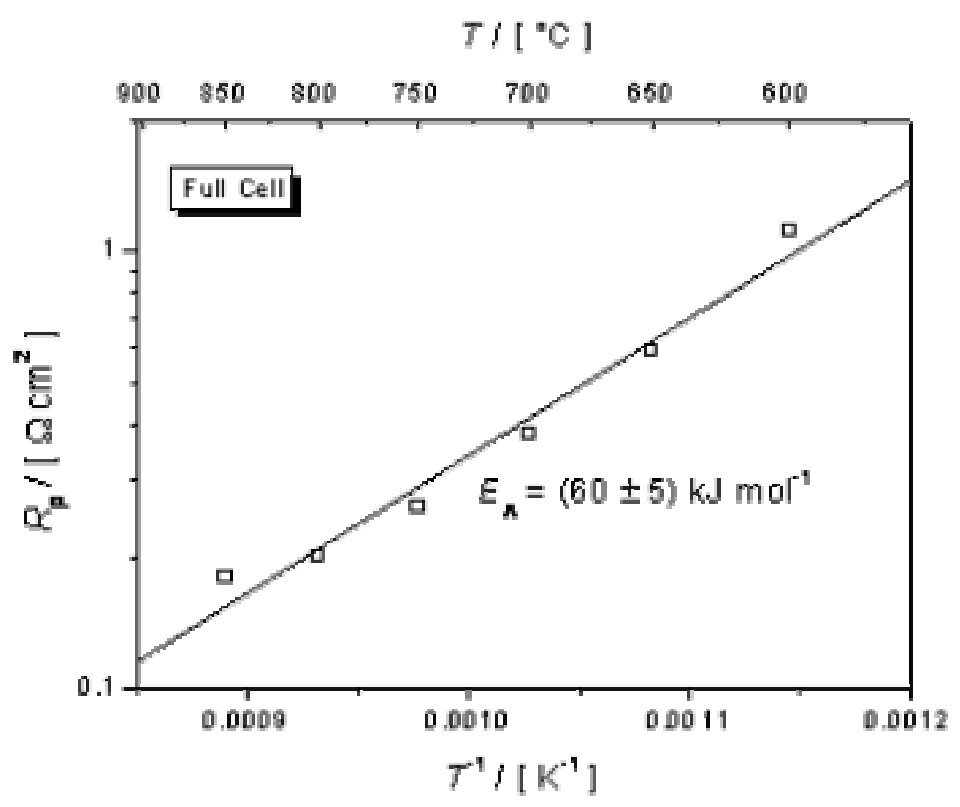

Figure 7. Arrhenius plot of the area-specific full cell polarisation resistance cut from the same sample measured in ambient air in the temperature range $600^{\circ} \mathrm{C}-850^{\circ} \mathrm{C}$. The activation energy $\left(E_{a}=60 \mathrm{~kJ} / \mathrm{mol}\right)$ has been derived from the Arrhenius equation.

\section{Conclusions}

In summary, single-sided gas changes in conjunction with differential analysis of impedance data allows the response from a single electrode in the full cell to be observed. The rate of degradation of the composite LSCF+CGO electrodes is greater by a factor of two in atmospheric air compared to synthetic air, possibly due to a difference in water and $\mathrm{CO}_{2}$ content. The degradation of symmetric cells gives rise to a change in the impedance spectrum in a frequency range which is overlapping with the range where changes take place at partial pressure changes at high $p \mathrm{O}_{2}$, indicating a change in the oxygen exchange rate. Subtraction of the anode contribution from the full cell $R_{\mathrm{p}}$ yields a value for the cathode polarization resistance (incl. anode diffusion and conversion losses) close to that measured on symmetrical cells.

\section{Acknowledgments}

The authors are thankful for the technical assistance from O. Hansen, H. Henriksen, and S. Koch. Financial support from the Danish Public Service Obligation PSO-Eltra5849 and Energinet.dk PSO contract no. 2006-1-6493 is gratefully acknowledged.

\section{References}

1. S. B. Adler, Chem. Rev., 104, 4791 (2004).

2. B. C. H. Steele, Solid State Ionics, 86-88, 1223 (1996).

3. B. C. H. Steele and J.-M. Bae, Solid State Ionics, 106, 255 (1998).

4. A. Hartley, M. Sahibzada, M. Weston, I. S. Metcalfe and D. Mantzavinos, Catalysis Today, 55, 197 (2000). 
5. A. Hagen, M. Menon, S. Ramousse, P. H. Larsen, R. Barfod, and P. V. Hendriksen in: Proceedings of the Sixth European Solid Oxide Fuel Cell Forum, M. Mogensen, Editor, European Fuel Cell Forum, Lucerne, Switzerland, p.930 (2006).

6. M. Mogensen, P. V. Hendriksen, in High Temperature Solid Oxide Fuel Cells. Fundamentals, Design, and Applications, Eds. S. C. Singhal, and K. Kendall, p. 261, (2003).

7. S. Uhlenbruck, A. Mai, V. A. C. Haanappel, F. Tietz, H. P. Buchkremer and D. Stöver, in: Proceedings of the Seventh European Solid Oxide Fuel Cell Forum, Ed. J. A. Kilner, P0627, European Fuel Cell Forum, Lucerne, Switzerland (2006).

8. F.Tietz, V.A.C.Haanappel, A.Mai, J.Mertens, D.Stöver;; J. Power Sources, 156, 20 (2006).

9. E. Ivers-Tiffée, A. Weber, H. Schichlein, in Handbook of Fuel Cells - Fundamentals, Technology, and Applications, Ed. W. Vielstiech, H. A. Gasteiger, A. Lamm, Vol. 2, John Wiley \& Sons, Ltd., (2003).

10. A. Esquirol, N. P. Brandon, J. A. Kilner, M. Mogensen, J. Electrochem. Soc., 151, A1847 (2004).

11. V. Dusastre, J. A. Kilner, Solid State Ionics, 126, 163 (1999).

12. W. G. Wang, M. Mogensen; Solid State Ionics, 176, 457 (2005).

13. C.-S. Hsu, B.-H. Hwang; J. Electrochem. Soc. 153, A1478 (2006).

14. S. B. Adler, J. A. Lane, and B. C. H. Steele, J. Electrochem. Soc., 143, 3554 (1996).

15. S. H. Jensen and M. Mogensen, submitted to J. Electrochem. Soc., (2006).

16. S. H. Jensen, PhD Thesis, Risoe National Laboratory, Roskilde, Denmark, (2006).

17. P. V. Hendriksen, S. Koch, M. Mogensen, Y. L. Liu, and P. H. Larsen, Proceedings of the International Symposium on Solid Oxide Fuel Cells VIII, Eds. S. C. Singhal, and M. Dokiya, PV2003-07, p. 1147, The Electrochemical Society Proceedings Series, Pennington, NJ (2003).

18. R. Barfod, A. Hagen, S. Ramousse, P.V. Hendriksen, and M. Mogensen, Fuel Cells, 6, 141 (2006). 